\title{
Beyond the Walls: Sites of Trauma and Suffering, Forgotten Australians and Institutionalisation via Punitive 'Welfare'
}

JACQUELINE Z. WILSON

\footnotetext{
$\mathrm{O}$ ne of the least known fields of Australian public history is that of women's and children's welfare and incarceration, and of the institutions in which that history was played out over almost two centuries. Today only a handful of such sites dating from the period of convict settlement remain across Australia in varying states of disrepair and neglect. Of these, the earliest, by far the most extensive in area and the only one that spans the period from early colonisation to the modern era is the Parramatta Female Factory Precinct (PFFP). This twenty-three hectare historical site is located in Sydney's western suburbs approximately twenty kilometres from the Sydney CBD. It comprises a complex of over seventy buildings, the oldest dating back to
}

\author{
Public History Review \\ Vol 20 (2013): 80-93 \\ (c) UTSePress and the author \\ ISSN: $1833-4989$
}


the early nineteenth century. It was founded originally as an institution to hold unassigned female convicts and their children and came to include an orphanage, a mental asylum, a girls' home and, from 1980 to 2010, a women's prison. ${ }^{1}$

Given its size, longevity and diversity of uses over the years, the PFFP thus stands today as the premier example of the institutionalisation and imprisonment of women and children in Australia. Its story takes us from the nation's colonial beginnings through to the recent child-welfare regimes of the twentieth century. As such, it serves also as a lens on the peculiarly brutal nature of those regimes which has been brought into the public gaze over recent decades by a series of government inquiries. ${ }^{2}$ These inquiries have drawn attention both to the sites as venues of the abuses reported, but also, especially, to those who experienced life behind their walls. Thousands of former inmates came forward to recount sustained, horrific experiences at the hands of uncaring staff members who were enacting equally uncaring policies within a system of such unconscionable callousness and cruelty. This moved the federal government to offer a formal apology to the victims. ${ }^{3}$ This group, numbering around half a million, have become collectively known, courtesy of the title of the 2004 Senate inquiry, as the 'Forgotten Australians'. ${ }^{4}$

As the stories of the Forgotten Australians are perceived as being intrinsically linked to the sites of their institutionalisation, the natural next step is to begin to rewrite those sites' histories to reflect the disparity between their official purport while operational and the realities that came to light in the inquiries. Such historical revision must incorporate as fully as possible the myriad human stories the sites embody. This prospect highlights the potential of sites such as, especially, the PFFP, to stand as both a tourist venue and educational facility, à la Sydney's Hyde Park Barracks and Tasmania's Port Arthur Historic Site.

With such ideas come questions: How should the sites be interpreted and by whom? Whose stories are to be told? Who will tell them and in what form? To these must be added the physical problems: the sheer size of PFFP, for instance, and the neglected state of many of its buildings, present problems of scale and cost that automatically entwine with questions of interpretation and representation, given that they may necessitate rigorous prioritising when it comes to restoration.

One is reminded at this point of political scientist Carrol Bacchi's question: 'What is the problem represented to be?' That is, whose version of the problem(s) will be foregrounded, what aspects will be omitted and 
in what ways will the nature of the problem(s) be thus defined $?^{5}$ If we consider the 'problem' to reside in the development of former institutions such as PFFP as public history sites, the present article may be read as an attempt at framing the problem in the light of Bacchi's approach by considering both the nature of individual narratives and how they can provide insights into the nature of institutionalisation and the potential role of the historical institution itself as a venue for representing such narratives.

The overriding consideration for the public historian, when exploring new histories of sites or histories that contest previous accounts, must be to achieve the optimum approach that will provide a voice for those hitherto silenced - in this case the women and children who were held against their will behind the walls. Due account must be made of competing narratives - for example, the necessarily conflicting points of view of former inmates compared to those of former staff members - and as these narratives are most often those of stakeholders, the ensuing debates can be highly emotive. Nor is stakeholder status a necessary condition for disputes to become markedly contentious. Witness the recent debate, conducted in the pages of the conservative magazine Quadrant and the Fairfax press, between Quadrant editor Keith Windschuttle and journalist Rick Fenely, as to the veracity of the personal accounts given by former inmates of the Kinchela Boys Home. ${ }^{6}$ In these ways we are reminded that the sites themselves are part of a wider range of stories, encompassing welfare regimes that impacted on lives far beyond the institutional walls.

The Forgotten Australians are by definition those who suffered institutionalisation in their youth. For many, such institutionalisation occurred in Parramatta, and in other, equally awful, sites of similar purpose. But as I will show, it is also important to consider carefully just what we mean by 'institutionalisation', and to take under consideration the idea that the subjective experience associated with it does not necessarily require physical confinement behind a wall. Pursuant to this, I propose to recount aspects of my own experiences as a State ward, conceptualising them in the light of, especially, Kerry Carrington's study of the relationship between wardship and the welfare apparatus, and the work of Harold Garfinkel on so-called 'ceremonies of degradation'. I hope also to show that the treatment meted out to State wards, whether incarcerated or not, routinely violated their Human Rights. I will then consider the potential for sites such as Parramatta to be developed as public history venues in the form of educational centres, museums and focus-points of redemptive social memory within the paradigm of 'Sites of Conscience'. Touching on the work of feminist theorist bell hooks, I 
argue that such development has the potential to effect radically transformative educational outcomes and hence salutary effects on the public sensibility.

\section{A Personal ACCOUNT}

In 1981, at the age of fifteen, I was made a ward of the State of Victoria. I had grown up in what reductionist welfare-speak terms a 'dysfunctional family' and from an early age had experienced numerous ineffectual 'interventions' by welfare authorities and/or police that saw me placed in a succession of institutions for relatively short periods. I had attended twenty different primary schools, and had spent time, variously, in Salvation Army hostels, Allambie Reception Centre, foster care, the Society for the Prevention of Cruelty to Children's orphanage, Department of Housing accommodation, motels and an endless series of ad hoc, low-quality rentals.

By the time I turned fifteen, I had been thrown out of home and was given the 'choice', by the family's youth worker, of homelessness or becoming a ward of the State. I quickly discovered that for me the wardship process was hardly any improvement on what I had left. In some ways it was worse. What I suffered, once in the system, was more subtle, and undoubtedly far more common, than the gross abuses so often highlighted in the media and in the various official inquires. My central point is that it was - and is - close to the norm, and that this norm constitutes a quasi-institutionalisation that does not necessarily involve incarceration (of which, more below).

In the first place, I was shocked when the process began by my complete loss of what little autonomy I had left. I had been led to believe that wardship would give me some independence and financial security; the reality was that instead I was made to feel isolated and even more financially insecure by a new set of people. A succession of welfare professionals made it clear to me, both tacitly and explicitly, that my situation, and the dysfunctional condition of my family, was considered essentially $m y$ fault. Most frightening for me, I was given responsibility for finding my own accommodation.

After a brief period in inadequate foster care and strictly temporary accommodation in Hope Street Hostel - a halfway house for homeless students, despite my new status as a minor under the guardianship of the State - I found myself without a place to live. I was sleeping in squats, in parks, in houses so badly kept they made the 'dysfunctional' domestic environment I had left behind look good, on various couches courtesy of friends whose resources were only marginally better than 
mine, constantly scrambling and hustling for any sort of roof over my head I could manage.

It was at that point that my case-worker, a social worker whom I shall call Hazel, put it to me that my efforts to find stable accommodation were not adequate, and that unless I did so she would have 'no alternative' but to have me sent to the female youth 'training centre' Winlaton, in Melbourne's outer-eastern suburbs. It is important to be clear, at this point, on the nature of this prospect. Winlaton was a high-security correctional facility; 'training centre', in other words, is a euphemism for prison. This highlights a key aspect of child-welfare which I will discuss in due course: the close affinity between the welfare system and carceral institutions. Similarly, of course, Parramatta 'Girls' Home' was not a 'home'; it was a prison.

To sum up: the State having failed to provide me, its ward, with a viable place to live, the State's representative charged with my care was now threatening me with indefinite imprisonment for the 'crime' of being homeless. 'Threaten' is not overly emotive: Hazel's manner toward me was at times extraordinarily autocratic and aggressive: she made it very clear that Winlaton would be the 'option' if I didn't sort out my accommodation. She further intimated that procedural 'mistakes' could sometimes occur that would see a juvenile placed in an adult correctional facility. I later learned that I was not alone in receiving such a warning; the ploy was reserved for wards the workers deemed especially 'uncooperative'. ${ }^{7}$ Even given such an incentive, I could not magically find a place to live. But an older friend at the time teed up her housemates to verify (falsely) that I was living at their share-house. Their readiness to lie for me, a comparative stranger, to the welfare authorities was all that kept me out of the 'training centre'.

\section{Penal Welfarism}

It is important to note that the welfare workers of whom I am speaking were doing little more than reflecting an entirely normative paradigm, which ethnographer Loic Wacquant conceptualises as 'the penalisation of precariousness' ${ }^{8}$ As criminologist Kerry Carrington observes, in her study of what she terms 'penal welfarism', ${ }^{9}$ the long-term incarceration of State wards whose only 'offence' was that they were State wards was accepted practice until very recently. This involved a 'strategic nexus between child welfare and punishment' as facilitated through a symbiosis between the cohort of welfare professionals and the children's court: $^{10}$

Regimes of penal welfarism allowed children's court 
proceedings to become focused on the character and nature of the individual child and his or her family background and not the offence. Children who were neglected, destitute or abused came before the same courts as children identified as delinquent, and were sentenced to the same or similar institutions, and treated as products of the same problem - the dysfunctional family. Consequently the administrative apparatus surrounding the children's courts - community service departments and institutions - did not distinguish between neglected children or delinquent children. ${ }^{11}$

Carrington approaches the issue as an exemplar of what Foucault called 'bio-power' - the State's dual attack on deviance via various modes of compulsive management of the 'body' of the individual and the 'social body' ${ }^{12}$ In thus exercising such power, by utilising its carceral potential upon children manifestly guilty of no criminal or moral offence, the State was in blatant violation of Article 9 of the UN Declaration of Universal Human Rights: 'No one shall be subjected to arbitrary arrest, detention or exile. ${ }^{13}$

Apart from the unhelpfulness of case workers, much of the practical difficulty of being a ward of the state stemmed, straightforwardly, from outright poverty. I received an allowance of thirty dollars a week - about half the adult dole at that time (and the adult dole was widely acknowledged as an inadequate income) - from which I was expected to get about, and feed, house and clothe myself. I had left home with only the clothes I stood up in and virtually no possessions - and the social workers knew this. But the availability of such adjunct benefits as food vouchers was strictly rationed, and subject always to a daunting regime of scrutiny and didactic moralism.

School was another major problem. I wanted to stay at school but it was almost impossible with nowhere to stay, no money and no support. And yet staying at school was the focus of another threat from the case workers: my wardship, with all its 'benefits', was conditional on my continued enrolment - I had to stay at school to remain a ward of the state, and, once again, to avoid the 'training centre' where there were supposed educational facilities. So after receiving a fragmented primary education, courtesy of my family situation, I got a fragmented secondary education under the auspices of the State welfare system. (After years of enrolling at schools wherever I happened to be living, I finally completed Year 12 at age twenty-five.) 
I was a ward of the State of Victoria for two years. In that time, noone acknowledged my past, let alone counselled me about it. In fact I was explicitly told that I had been in care as a child 'only once'. I was never informed of my entitlements. I was told nothing of my legal rights. My abiding experience of the welfare workers was humiliation and blame. The effect of such treatment is insidious. I was dismissed, disapproved of and disbelieved so unanimously, so systematically, that by the time I was discharged from wardship, I had come to distrust my own memories.

In 1993 through Freedom of Information I accessed my Community Services file. Its contents shocked me profoundly. Not only were my memories of the case workers' hostility correct, but that hostility, it turned out, originated, and was affirmed, in the documents. Incredibly, the Departmental youth worker's report that formed the basis of my admission and treatment as a ward relied entirely on his own fragmented, subjective and moralistic viewpoint of my domestic situation; it was blatantly biased and contained gross factual errors; it was, quite literally, libellous - as well as being unreflective, banally moralistic, judgemental and unprofessional. I was adjudged pretentious, lazy, slovenly, violent, even sexually aberrant. Once again it should be noted that, in the context of the prevailing high-scrutiny welfare paradigm, such judgements are not remarkable. What Carrington terms the 'visibility of otherness' imposed upon adolescent girls in public housing more or less automatically produced perceptions among welfare professionals of sexual precociousness and/or moral deviance. ${ }^{14}$

Even more confronting was the realisation that every subsequent case worker had unhesitatingly accepted as truth that first damning report, and no-one had ever raised any of it with me, or thought to check it, or given me the slightest opportunity of defending myself against it. They simply couched their own reports and judgements - and their personal treatment of me - in its pejorative light. It is not unreasonable, I suggest, to deem such practice as nothing short of Kafkaesque.

\section{ABUSE AND EXTRA-MURAL INSTITUTIONALISATION}

My case exemplified a gross lack of accountability that long characterised the child welfare system in Australia. Once I had seen my file, I went to considerable trouble collecting evidence to refute the reports' more defamatory passages, and sought legal advice regarding a possible suit against the Department of Health and Community Services. I was told flatly that despite the obvious truth and moral justice of my claim, I had no legal redress: such departments are indemnified against 
any claims arising from mere incompetence - however gross.

In the light of the many care-leavers' narratives of institutional suffering brought to light by the inquiries, the question arises: Can it be said that a ward such as myself who was not institutionalised, and who suffered no physical maltreatment from my care-workers, was abused by the welfare system and/or its representatives? The answer depends on how one defines 'abuse'. The Australian Institute of Family Studies defines non-physical child abuse in terms of harm incurred as a consequence of 'emotional maltreatment' and / or 'neglect'. ${ }^{15}$ I would argue that repeatedly removing a child from an abusive environment, then returning the child to that environment, then subsequently denying that the child was actually abused - or even that the removals into care had occurred - while purporting to protect the child from the abuse, amounts to something approaching psychological torture. Consider also that while the child is in 'care' she is threatened with imprisonment, periodically called by pejorative names derived from a secret dossier on her, is compelled to get an education while at the same time effectively denied access to this, is kept her in poverty, denied elementary natural justice or even elementary human sympathy, and, at the end of the day, the perpetrating functionaries remain hidden behind a wall of unaccountability. By any reasonable standard, I suggest, this constitutes a regime of abuse. ${ }^{16}$

The above account may give rise to some questions as to the connection between a narrative such as mine - a narrative typical of many former wards - in which incarceration played only a notional and one might say emotive role, and an institutional site such as PFFP. The connection is twofold. Firstly, as noted above, the site, like others of its kind, must be seen in various ways representative of a wider body of narratives than merely those directly associated with its operational history. PFFP was recently the venue of a major academic conference convened to discuss the social and historical meaning of the site itself and its potential for development as a public history venue. Included among those who attended was a significant number of persons identifying as Forgotten Australians (myself included), many of whom had never previously set foot within the Precinct, but who acknowledge the site as generically representative of them and their experiences.

Secondly, and related to the first point, there is a key aspect I flagged earlier: that State wards who do not experience incarceration, or the supposed 'benefits' of a 'training centre', are still subject to what I term 'extra-mural institutionalisation'. This is a result of the constant and intense levels of official (and fully documented) scrutiny imposed on 


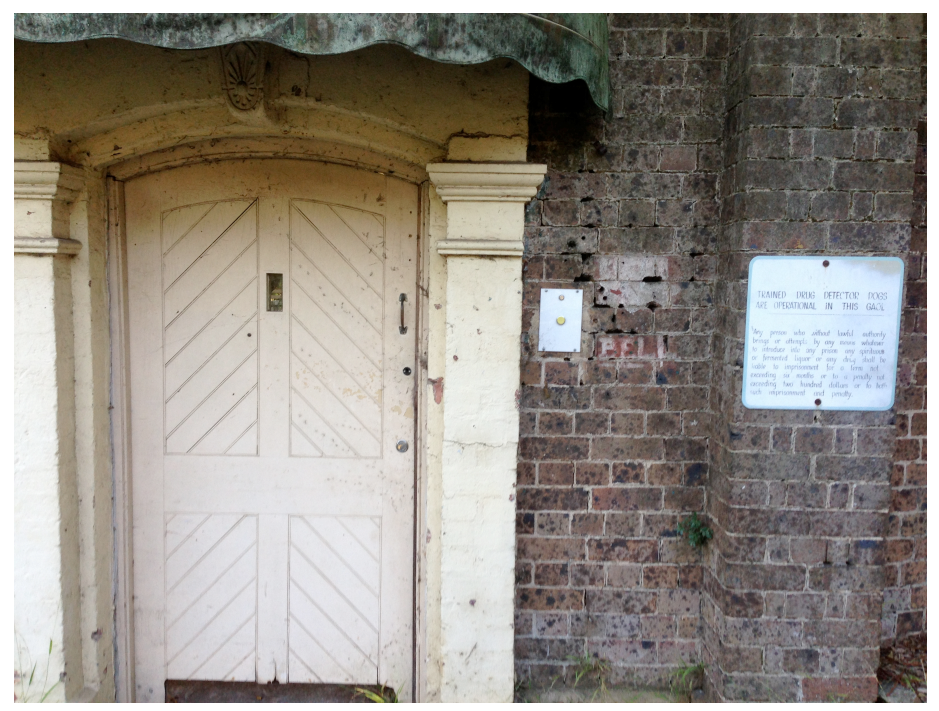

Above: a detail of the Norma Parker Site at the Parramatta Female Factory Site (photograph Paul Ashton). Below: part of the Parragirls Memory Quilt 1887-1974, quilt design by Bonney Djuric (photograph Paul Ashton)

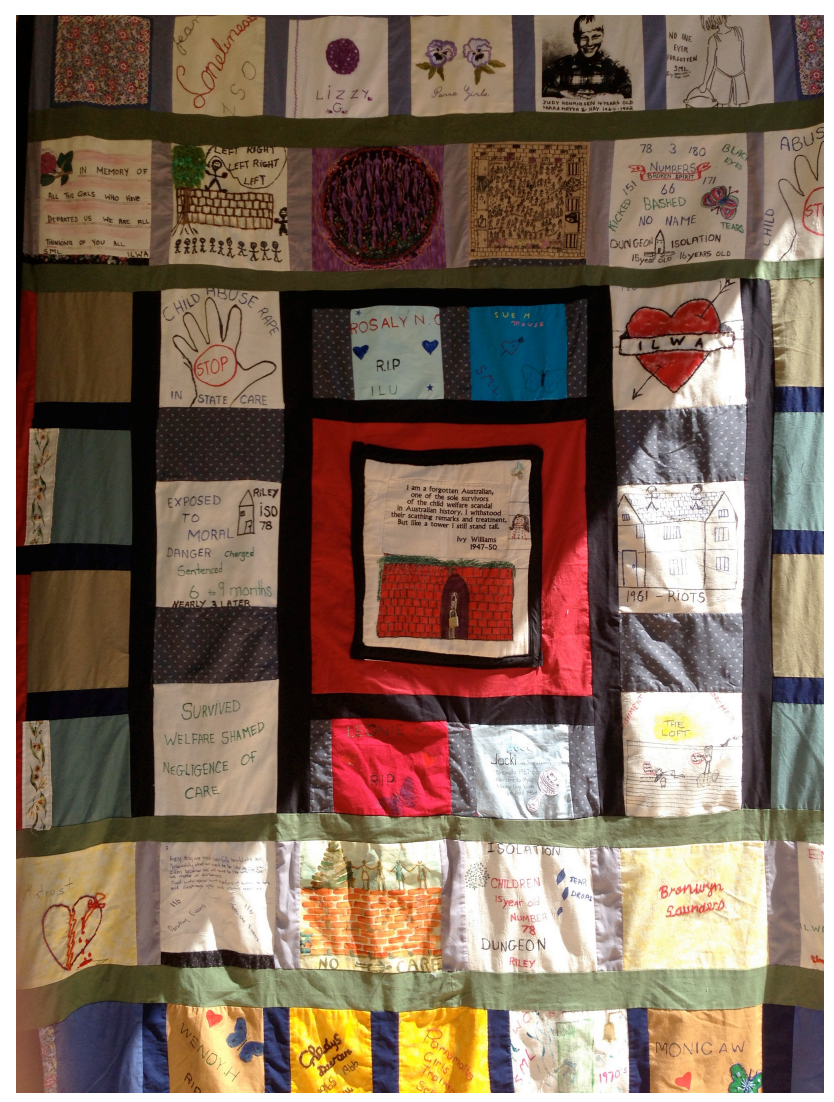


them - scrutiny accompanied and reinforced by credible threats of actual incarceration. To the ordinary, mainstream citizen, incarceration constitutes a profound disjuncture from normal life - an abrupt and radical transition to an alien state of being. To the State ward who is nominally at large but who lives under the ubiquitous 'gaze' of the system, incarceration may well amount to more of a shift in degree along a continuum of anxiety, dispossession, subjective constraint and erosion of self. The individual faced with the prospect of incarceration or even simply threatened with it is, in other words, already significantly institutionalised by virtue of the prospect of threats themselves and the systemic regime of oppression from which they originate, and in which the individual is immersed. (This is not, I hasten to add, to minimise or negate in any way the stories of those who did find themselves in places such as Winlaton, Parramatta, Hay, Tarana or Beltara; the total institution is still the total institution for those who have experienced it on their skin.)

In considering the question of the self, and the radical undermining of self-worth - which was epitomised within the correctional institutions especially via their grotesque treatment of new arrivals ${ }^{17}$ - but beginning outside, with the system's reliance on the judicial process, I am reminded of the rituals of 'public denunciation' and 'moral indignation' embodied in Harold Garfinkel's notion of 'degradation ceremonies' used to define and shun individuals as the embodiment of reviled categories of transgressor. ${ }^{18}$ Garfinkel cites, as an easily visible example of this process, the criminal justice system, especially the rituals and procedural trappings of the courts. ${ }^{19}$ In outlining his schema, he notes the centrality in the process of a 'ritual destruction' of the individual's social identity, such that the person is thereafter regarded as having always belonged to the proscribed category. Such 'destruction' is an abiding lament of many Forgotten Australians of my acquaintance, who remain conscious of the seeming permanence of their 'othering'. I note, at this point, Article 5 of the UN Declaration of Universal Human Rights: ‘No one shall be subjected to torture or to cruel, inhuman or degrading treatment or punishment. ${ }^{20}$

It is important to realize that being a ward of the state - or indeed in any situation requiring intervention - is intrinsically extreme, in our society of nuclear families, and the child arrives in that situation usually via the utmost extremes at home. The workers I encountered evinced no intuitive sense of the child's experience of those extremes. The individual particulars of my wardship notwithstanding, there is no reason for me to think that its handling was especially unusual. The methodological 
inadequacies revealed in my file were obviously systemic and accepted as the norm. And successive inquiries culminating in the 2004 Senate inquiry confirmed this. So what of all the others caught up in the welfare system, being dealt with by those same workers?

\section{SITES OF FORGETTING}

As I said in my introductory remarks, the history of women's and children's institutionalisation - which in the modern era embraces the history of the Forgotten Australians - is a little-known area of Australian history. As such, there have been calls in recent years for it to be included as a mandated area of study in the forthcoming nation-wide Australian Curriculum in History (ACH). In 2011, during the ACH's development, former Senator Andrew Murray in particular advocated for the Forgotten Australians' inclusion alongside other related and more well-known topics which are mandated. As he put it: 'It is vital that the 30,000-50,000 Indigenous Australians of the Stolen Generations have their history taught... It is extraordinary that the 450,000-500,000 nonindigenous Australians who experienced similar trauma will not have their history taught. ${ }^{21}$ The then Education Minister, Peter Garrett, effectively dismissed Murray's concerns by stating that although study of the Forgotten Australians was not mandated, the curriculum presented 'a number of opportunities' for it to occur. ${ }^{22}$ An examination of the ACH reveals, however, that those 'opportunities' are in fact few, vague, placed at a year level which is arguably age-inappropriate for the topic and would require a specific commitment on the part of teachers even to find. ${ }^{23}$

This can only be seen as an opportunity missed and one which I suggest falls to those who represent the past in the present to redress, through a focus on the informative and education potential of the PFFP site. The Parramatta Precinct stands as the prime example of the institutionalisation and incarceration of women and children in Australia from our colonial beginnings to today. It thus has the potential to play a key role in such studies as a major educational resource. As Laurajane Smith notes, 'heritage' sites have an intrinsic resonance with children, and the practice of 'taking the children' to visit such sites, whether in the context of family outings or as educational activities, has a long history. As she puts it: 'heritage is a process of negotiating a range of values and meanings, and is a process in which the experiences and values of children, childhood and adulthood are negotiated and re/ created'. ${ }^{24}$ Further to this is the site's manifest potential as a significant 'dark tourism' destination, with the possibility of future registration as a Site 
of Conscience. ${ }^{25}$ As many international examples show, social memory is often affirmed, and national identity thus served, by sites that embody the darkest narratives. But the Parramatta Precinct also exemplifies radically disparate experiences of citizenship, civic participation and democracy. It therefore has the potential to feature in educational depth studies in a range of subjects beyond the mere historical. Further, as a Site of Conscience it can potentially provide a transformative nexus between Heritage and restorative justice.

Feminist theorist bell hooks speaks of the 'transformative' potential of acquiring the capacity for critical thinking through education. ${ }^{26}$ In particular hooks utilises visual media to promote such constructive scrutiny and questioning. She is centrally concerned with the lifechanging transformations that empower individuals to overcome oppressive socio-economic, ethnic and / or gender-based circumstances. But I suggest that a transformation of potentially equal importance occurs when learners discover their capacity to recognize, question and fearlessly critique their own assumptions. As a Site of Conscience, the Parramatta Precinct has the capacity to effect such transformations. It is not just about visual spectacle; the site has enormous potential to house artistic, literary and cultural exhibits and events, linked with its diverse architectural settings representing an array of 'moments' in Australia's journey from penal colony to nation-state.

\section{ENDNOTES}

${ }^{1}$ Parramatta Female Factory Precinct Association, 'Heritage Information' (Online). Available: http: / / www.parragirls.org.au/heritage.php (Accessed 15 December 2013), nd.

${ }^{2}$ See Queensland Government, Forde Inquiry Report: Commission of Inquiry into Abuse of Children in Queensland Institutions (Online), 1999. Available:

http: / / www.communities.qld.gov.au / resources / communityservices / community / forgotten-australians / forde-comminquiry.pdf (Accessed 12 Dececember 2013); Senate Committee on Community Affairs, Forgotten Australians: A Report on Australians who Experienced Institutional or Out-of-home Care as Children, Australian Government, Canberra, 2004; and South Australian Government, Children in State Care Commission of Inquiry: Allegations of Sexual Abuse and Death from Criminal Conduct (Online), 2008. Available:

http: / / www.sa.gov.au/ upload / franchise / Crime, $\% 20$ justice $\% 20$ and $\%$ 20the $\% 201$ a w/Mullighan_Inquiry/CISC\%20-\%20Introduction.pdf (Accessed 15 December 2013).

${ }^{3}$ Prime Minister Kevin Rudd, transcript of address at the apology to the Forgotten Australians and former child migrants, Great Hall, Parliament House, 16 November 2009 (Online). Available: http: / / pandora.nla.gov.au/pan/110625/200911161801/ www.pm.gov.au/node/6321.html. Accessed 20 Dec. 2013.

${ }^{4}$ Senate Committee on Community Affairs, op cit.

${ }^{5}$ See Carol Bacchi, Analysing policy: What's the problem represented to be? Pearson Education, Frenchs Forest, 2009; also Carol Bacchi, 'Introducing the "What's the Problem 
Represented to be?" approach', in Angelique Bletsas and Chris Beasley (eds), Engaging with Carol Bacchi: Strategic Interventions and Exchanges, University of Adelaide Press, Adelaide, 2009, pp21-24.

${ }^{6}$ See Rick Feneley, 'They Were Numbers; Now They Have Voices', Sydney Morning Herald, 30 November 2013 (Online). Available:

http: / / www.smh.com.au / national/ they-were-numbers-now-they-have-voices20131129-2ygzm.html (Accessed 27 December 2013); Keith Windschuttle, 'Investigative Journalism, Fairfax-style', Quadrant Online (Online), 2 December 2013. Available: https:/ / quadrant.org.au/opinion/ bennelongpapers / 2013/12/investigative-journalism-fairfax-style/ (Accessed 27 December 2013); Rick Fenely 19 Dec. 2013, 'Kinchela Boys Home: Response to Keith Windschuttle', Sydney Morning Herald (Online). Available: http: / / www.smh.com.au/comment/ kinchela-boys-home-response-to-keithwindschuttle-20131219-2zmkj.html (Accessed 27 December 2013).

${ }^{7}$ See Jacqueline Wilson, Prison: Cultural Memory and Dark Tourism, Peter Lang, New York, 2008, pp99; 112 note 18.

${ }^{8}$ Loic Wacquant, 'The Prison is an Outlaw Institution', The Howard Journal, vol 51, no 1, 2011, p6.

${ }^{9}$ Kerry Carrington, 'Punitiveness and the Criminalisation of the Other: State Wards, Unlawful Non-citizens and Indigenous Youth', Somatechnics, vol 1, no 1, 2011, pp33, 40 .

${ }_{10}$ ibid, p40.

11 ibid. p33.

${ }^{12}$ Foucault cited in ibid, p31.

${ }^{13}$ United Nations, Universal Declaration of Human Rights (Online), nd. Available: http:/ / www.un.org/en/documents/udhr/ (Accessed 2 August 2013).

${ }^{14}$ Kerry Carrington, Offending Girls: Sex, Youth and Justice, Allen \& Unwin, St Leonards NSW, 1993, p42.

${ }^{15}$ Australian Government, Australian Institute of Family Studies, 'What is Child Abuse and Neglect?' (Online), 2002. Available: http: / / www.aifs.gov.au/cfca/pubs/ factsheets/a142091/ (Accessed 15 December 2013).

${ }^{16}$ See ibid, especially sections on 'Emotional maltreatment', points 1-4, and 'Neglect', points 1-4.

${ }_{17}$ See, eg, Parramatta Female Factory Precinct Association, 'Parramatta Girls Home: Environment, Routines and Procedures' (Online), nd. Available: http: / / www.parragirls.org.au / parramatta-girls-home.php (Accessed 14 August 2013).

${ }^{18}$ Harold Garfinkel, 'Conditions of Successful Degradation Ceremonies', American Journal of Sociology, vol 61, no 5, 1956, pp420-24.

19 ibid, p424.

${ }^{20}$ United Nations, op cit.

${ }^{21}$ Murray quoted in Milanda Rout, 'Call to include history of children mistreated in care in curriculum', The Australian, 26 September 2011.

22 ibid.

${ }^{23}$ See Jacqueline Z. Wilson, Peter Russell and Simon McCart, 'The Parramatta Female Factory Precinct and the National History Curriculum, in Paul Ashton and Jacqueline Z. Wilson (eds), Silent System: Forgotten Australians and the Institutionalisation of Women and Children, Australian Scholarly Publishing, Melbourne, forthcoming 2014.

${ }^{24}$ Laurajane Smith, 'Taking the Children: Children, Childhood and Heritage Making', in Kate Darien-Smith and Carla Pascoe (eds), Children, Childhood and Cultural Heritage, Taylor and Francis, Hoboken, 2012, p123.

${ }^{25}$ International Coalition of Sites of Conscience: Parramatta Female Factory Precinct Project (Australia): http: / / www.sitesofconscience.org/members/parramattafemale-factory-precinct-project/.

${ }^{26}$ bell hooks, 'Cultural criticism and transformation: part one: On cultural criticism: 
Why study popular culture?' Video presentation, Media Education Foundation (Online), 2006. Available: http:/ / www.youtube.com/watch?v=zQUuHFKP9s\&feature $=$ related (Accessed 27 September 2012). 